\title{
Mellom risiko og kontroll - en studie av eksplisitte modelleringsformer i norsk grunnskolelarerutdanning
}

\author{
Fride Lindstøl ${ }^{\star}$ \\ Fakultetet for humaniora, idretts- og utdanningsvitenskap, Institutt for estetiske fag, \\ Høgskolen $i$ Sørøst-Norge, Vestfold, Norge
}

\begin{abstract}
Sammendrag
Å være lærerutdanner skiller seg fra andre stillinger innenfor høyere utdanning: Lærerutdanneren underviser både i fagstoff og i hvordan studentene kan lære bort og adaptere fagstoffet i klasserommet. Det at lærerutdanneren underviser i det å undervise, har implikasjoner for hvordan undervisningen planlegges, gjennomføres og analyseres i lærerutdanningen - undervisningens form blir en del av budskapet. Lærerutdannerens arbeid handler derfor om å utforme, velge og sette i spill aktiviteter og oppgaver som kan adaptere fag, forskning, didaktikk og teori til klasserom og profesjonen. Utforming og montasje av de ulike delene eller episodene i et undervisningsforløp kan betegnes som undervisningsforløpets dramaturgi. I denne artikkelen har jeg gjort en dramaturgisk analyse av tre lærerutdanneres undervisning for å identifisere og beskrive hvordan de bruker eksplisitte modelleringsformer, og hva som skjer når de bruker dem. I etterkant av den dramaturgiske analysen har jeg gjort en konvensjonell innholdsanalyse av intervjudata for å undersøke hvordan lærerutdannerne selv forklarer formålet og erfaringer med å bruke eksplisitt modellering i undervisningen. Analyse av tre lærerutdanneres undervisningspraksis sammenfattes i en modelleringsstige som visualiserer hvordan enkelte former for eksplisitte modelleringsformer tilbyr en egen sirkulær dramaturgi. Studien antyder og drøfter også på hvilken måte modelleringsstigen kan fungere som en dramaturgisk modell, som kan brukes som utgangspunkt for lærerutdanneres planlegging, gjennomføring og analyse av egen undervisning. Studien er et bidrag til å utvikle og forske på hvordan eksplisitte modelleringsformer kan brukes for å skape sammenheng mellom praktisk lærerarbeid og teoretisk metarefleksjon i lærerutdannerens undervisning. Innsamling av data er gjort i profesjonsverksted, som kan forklares som en læringsarena hvor lærerutdannere fra ulike fag samarbeider om å transformere overordnede mål for utdanning til høgskoledidaktiske aktiviteter og arbeidsformer.
\end{abstract}

Nøkkelord: Lererutdanning; undervisning; dramaturgi; eksplisitt modellering; teori og praksis

\section{Summary}

The work of teacher educators differs from the work of other college or university educators. In addition to teaching his/her subject, the teacher educator teaches his/her students how they can adapt their subject knowledge to the classroom. The fact that the teacher educator teaches how to teach has

^Korrespondanse: Fride Lindstøl, Høgskolen i Sørøst-Norge, Postboks 235, 3603 Kongsberg. Epost: Fride.1.hansen@usn.no

(C) 2017 Fride Lindstøl. This is an Open Access article distributed under the terms of the Creative Commons Attribution 4.0 International License (http://creativecommons.org/licenses/by/4.0/), allowing third parties to copy and redistribute the material in any medium or format and to remix, transform, and build upon the material for any purpose, even commercially, provided the original work is properly cited and states its license. 


\section{Fride Lindstøl}

implications for the planning, implementation and analysis of his/her classes - the form of his/her teaching becomes a part of his/her instruction. Thus, the teacher educator's work involves the development, selection and initiation of activities and tasks that can help to adapt knowledge, research and theory to the classroom and the profession. The design and assembly of the various parts or episodes of a pedagogical course can be described as a pedagogical dramaturgy. In this article I have made a dramaturgical analysis of three teacher educators' teaching in order to identify and describe the explicit forms of modelling they employ, and the consequences of their practice. I have also made a conventional content analysis of interview data, in order to examine how these teacher educators themselves explain their goals and experiences of their explicit modelling. The analysis of the teacher educators' practice is summarised in a modelling ladder that presents how explicit types of modelling comprise their own circular dramaturgies. The study discusses and proposes how a modelling ladder can function as a dramaturgical model that can provide a starting point for teacher educators in planning, implementing and analysing their own practice. The study is a contribution to research into how explicit modelling forms can be used in order to integrate teaching and theoretical metareflection in teacher educators' classroom practice. Data collection was made in a professional workshop, a learning arena where teacher educators from different subject areas co-operate in transforming overriding educational goals into didactic activities and working practices.

Keywords: Teacher education; explicit modelling; teaching; dramaturgi; theory and practical teaching

Received: April, 2017; Accepted: October, 2017; Published: December, 2017

\section{Innledning - larerutdannerens undervisning}

Feg har et faglig tema på agendaen, og starter alltid med å tenke på profesjon og didaktikk (...) Feg lager problemløsningsoppgaver som innbyr til à snakke matematikk, argumentere, stille spørsmål og forklare for andre. Etterpå har vi metasamtaler rundt erfaringen, hva gjorde vi nå, hvorfor gjorde jeg dette og hva er formålet med aktivitetene. Vi presiserer faglige begreper og språkliggjør erfaringer fra problemløsningsoppgaven. Etterpå jobber jeg teoretisk rundt denne (IML3).

Sitatet ovenfor viser hvordan en av lærerutdannerne som har deltatt i denne studien, forklarer hvordan hun adapterer fagstoff og forskning for å bruke det i undervisningen. Eksempelet illustrerer at det å undervise i en lærerutdanningskontekst kan handle om å velge og sette sammen aktiviteter og oppgaver som best mulig kan adaptere fag, forskning og teori til klasserom og lærerprofesjonen. Det at lærerutdanneren underviser i det å undervise, har implikasjoner for hvordan undervisningen planlegges, gjennomføres og analyseres i lærerutdanningen. Det betyr at måten man underviser på, og dermed undervisningens form, blir en del av budskapet (Loughran \& Berry, 2005). Som eksempelet ovenfor viser, holder det ikke å bare modellere ferdigutviklede metoder og arbeidsformer. En slik strategi kan fort bli forutsigbar og instrumentell og gi lite rom for kreativ nytenkning og for studentenes egne adapsjoner. Lærerutdannerens modelleringer må ivareta både et praktisk og et teoretisk perspektiv, der modellerte didaktiske situasjoner må åpnes opp og problematiseres gjennom teoretisk metarefleksjon (Ulvik \& Smith, 2016, s. 63).

Ulvik og Smith påpeker at en forutsetning for at undervisningen i lærerutdanningen skal være eksemplarisk og holde høy standard, er at lærerutdannerens evner som 
underviser settes på dagsorden, og at ansvaret som rollemodell bevisstgjøres (Ruys, Defruyt \& Aelterman, 2013, s. 74; Ulvik \& Smith, 2016). Hvordan skal didaktiske situasjoner modelleres for å sikre både et didaktisk repertoar og åpne opp for variasjon og nytenkning? Hvordan kan man sikre at teoretiske metakommentarer åpner opp og virker på det praktiske lærerarbeidet? Et utvalg av forskningslitteratur som presenteres i denne artikkelen, viser at lærerutdanningen trenger flere studier som problematiserer hvordan ulike modelleringsformer kan brukes til å sette både praktisk lærerarbeid og teoretiske perspektiver i spill, og få disse til å virke sammen i undervisningen. Slike studier fremviser praksis, men viser også noen muligheter for undervisning i fremtidens lærerutdanning. Et lærerutdanningsteam på arbeidsplassen min etablerte et prosjekt kalt profesjonsverkstedet (Lindstøl, 2016; Lindstøl, Bakke, \& Moe, 2015). Bakgrunnen var et ønske om å utvikle og forske på egen lærerutdanningspraksis.

Profesjonsverkstedet kan beskrives som en læringsarena der et flerfaglig team med lærerutdannere (fra pedagogikk, drama, norsk, matematikk) går sammen om å undersøke, dele og transformere mål og visjoner for grunnskolelærerutdanningen til konkret undervisning på campus. Profesjonsverkstedet har studenter på lærerutdanningen som primærmålgruppe, og sekundærmålgruppen er faglærerne som underviser på utdanningen. I etableringen av profesjonsverkstedet (2013) var formålet å kvalifisere studentene for profesjonsutøvelse. Lærerteamet samarbeidet om å utvikle og teste ut aktiviteter, medierende redskaper og læreprosesser med ulike kvaliteter som kunne styrke integrasjonen mellom teori og praksis, fag og pedagogikk, primært i undervisningen på campus. I presentasjonen av relevant forskningslitteratur viser jeg hvordan erfaringer og refleksjoner knyttet til ulike modelleringsformer ledet til følgende forskningsspørsmål:

På hvilken måte kan eksplisitte modelleringsformer brukes og settes sammen for å skape sammenheng mellom praktisk larerarbeid og teoretisk metarefleksjon i lcererutdannerens undervisning?

Jeg vil i neste avsnitt presentere forskning og teori som tematiserer eksplisitte modelleringsformer. Videre vil jeg presentere resultater fra en analyse av feltnotater og øktagendaer og intervjuer med tre involverte lærerutdannere. Resultatdelen vil avslutningsvis bli drøftet opp mot forskningslitteratur som tematiserer modellering, slik at studien kan få overføringsverdi til andre kontekster og lærerutdanningspraksiser.

\section{Eksplisitt modellering i lærerutdanningen}

I forskningslitteraturen presenteres modelleringstyper med flere formål. Det er modelleringer som tematiserer og setter i spill ulike kunnskapsformer i lærerutdanningen (Loughran \& Berry, 2005, s. 199; Lunenberg, Korthagen \& Swennen, 2007, s. 590). En distinksjon er skillet mellom implisitt og eksplisitt modellering. Implisitt modellering kan eksemplifiseres gjennom uttrykkene teach as you preach og walk the talk, og fremhever lærerutdanneren som rollemodell, uten at lærerutdanneren eksplisitt modellerer ønsket praksis (Aleccia, 2011, s. 63; Hogg \& Yates, 2013; Ulvik \& Smith, 2016). Implisitt modellering forstås som at læreren viser, forteller og gjør didaktiske 


\section{Fride Lindstøl}

valg, som kan karakteriseres som eksemplarisk praksis. Tross gode intensjoner og eksemplarisk praksis påpeker flere studier at studentene sjelden oppfatter implisitt modellering (Lunenberg et al., 2007, s. 590; Ulvik \& Smith, 2016, s. 63-64). Min forforståelse er at det er et strekk i feltet mellom implisitt og eksplisitt modellering. Overgangene er glidende og ikke bare enten - eller. Dette er et perspektiv jeg vil drøfte i siste del av artikkelen.

Mens implisitt modellering forklares mer som lærerens undervisningsstil eller form, forklares eksplisitt modellering som «The practice of intentionally displaying certain teaching behaviour with the aim of promoting student teachers professional learning» (Gallimore \& Tharp, 1992; Lunenberg et al., 2007, s. 589). Forklaringen viser at eksplisitt modellering handler om å vise (display) og bevisst velge spesifikke handlinger som kan konkretisere og utvikle lærerstudentenes kunnskaper, ferdigheter (certain teaching behaviour) og profesjonelle læring. Eksplisitte modelleringsformer kjennetegnes også ved at lærerutdanneren er bevisst på type modellering og formålet med den: "Deciding which aspects of practice to make explicit, how to make them explicit, and when so that they might be useful and meaningful for student-teachers is an ongoing dilemma in attempting to teach through explicit modelling» (Loughran \& Berry, 2005, s. 200). Det betyr at eksplisitt modellering krever en form for innramming som både kontekstualiserer og tydeliggjør modelleringens funksjon i undervisningsforløpets oppbygging og dramaturgi (Lindstøl, 2017a). Dette kan som tidligere nevnt gjøres «ved å tilføre metakommentarer ved å forklare underliggende pedagogiske valg og knytte disse til pedagogisk teori» (Ulvik \& Smith, 2016, s. 63). Et perspektiv som tematiseres i analysen, er hvordan lærerne kan utforme og sette sammen modelleringene slik at både praktisk lærerarbeid og teoretisk metarefleksjon settes i spill i undervisningen.

Hvilke typer eksplisitte modelleringsformer kan identifiseres i forskningslitteraturen? En kategori handler om å modellere eksempler og arbeidsformer fra skolen og lærerens hverdag, i denne studien kalt adapsjon til klasserommet. Ulvik og Smith påpeker at flere studier sier at studentene trenger innspill til hva de skal gjøre i klasserommet (Ulvik \& Smith, 2016, s. 63, 75). Det er altså ikke nok å snakke om god undervisning. Lærerutdanneren må også gjøre og vise det de sier: «doing in our practice that which we expect our students to do in their teaching» (Loughran \& Berry, 2005, s. 194). Slike modelleringsformer kan også forstås som konkret eksemplifisering av hvordan et fagstoff eller teori kan adapteres til ulike klassetrinn og lærerens praksis. Studentene kan introduseres for spesielle undervisningsferdigheter som for eksempel muntlige uttrykksformer (forelesning, fortelling, lede klassesamtaler) og arbeidsformer (problemløsning, casemetodikk). Lærerutdanneren kan også modellere deler av undervisningsforløp, som i denne studien er eksemplifisert som ulike måter å starte opp en time på.

En annen kategori er å modellere hvordan det teoretiske perspektivet kan bidra til at studentene tenker kritisk over praktisk lærerarbeid, i denne studien kalt modellering av teoretisk metarefleksjon. Kategorien begrunnes med at det å eksplisitt modellere arbeidsformer og metoder ikke er nok, studentene må også bli oppmuntret til å reflektere over 
meningen med modelleringen (Loughran \& Berry, 2005, s. 193, 200; Ruys et al., 2013). Et forslag til en måte å koble teori og praksis er å eksplisitt modellere underliggende pedagogiske valg og videre vise hvordan valgene kan analyseres ved hjelp av teori. Dette giøres ved at læreren modellerer hvordan metakommentarer kan knyttes til praktiske eksempler (Ruys et al., 2013; Ulvik \& Smith, 2016, s. 63). I denne sammenhengen poengterer Lunenberg at: "This means that the next step in modelling is to move on from making useful 'tricks' explicit to student teachers to connecting exemplary behaviour with theory» (Lunenberg et al., 2007, s. 592). Lærerutdanneren velger derfor ut teoretiske perspektiver og begreper, som bidrar til å fokusere på ulike kvaliteter ved praktiske situasjoner, og modellerer hvordan teoretiske "linser» kan gi form til analysen. Både form og nivå på analysen er noe som kan bidra til utvikling av studentenes profesjonsspråk (Lindstøl, 2016; Østrem, 2009). Modellering av analyser kan også fungere som modelltekster for skriftlige analyser, der det å bruke teori for å analysere praktiske eksempler er en grunnleggende ferdighet. Flere studier tyder på at lærerutdannere ikke alltid lykkes med å implementere teori i det praktiske arbeidet, men bygger undervisningen på personlige erfaringer, implisitt teori og "common sense» (Lunenberg et al., 2007; Ulvik \& Smith, 2016, s. 64).

I tillegg til å modellere didaktiske eksempler som etterfølges av teoretiske analyser, peker forskningslitteraturen på en tredje modelleringskategori. Ulvik og Smith forklarer kategorien på denne måten: «til forskjell fra andre, må lærerutdanneren kunne snakke om egen undervisning $\mathrm{i}$ teoretiske begrep for å modellere hvordan praksis og teori henger sammen" (Smith, 2005; Ulvik \& Smith, 2016, s. 74). Denne kategorien skiller seg fra forrige kategori fordi den har lærerutdannerens undervisning som objekt. Det er hvordan lærerutdanneren begrunner og komponerer undervisning som kommenteres og problematiseres. Kommentarene kan planlegges, for eksempel ved å presentere undervisningens formål, progresjon og dramaturgi, og deretter kontekstualisere. Metakommentarene kan også være spontane ut ifra erfaringer som giøres underveis i forløpet, og også ved at lærerutdanneren åpner opp for studentenes evaluering. Loughran og Berry kaller slike strategier «thinking aloud» (Loughran \& Berry, 2005, s. 590), og sier at denne modelleringsformen er en måte å hjelpe studentene til å bli bevisst på forholdet mellom handling (action) og intensjon (intent) (Lunenberg et al., 2007, s. 597). Fordi lærerutdanneren utsetter seg for åpen kritikk, oppleves denne modelleringsformen som spesielt risikofylt. Det er ikke alltid samsvar mellom lærerutdannerens formål og intensjon og studentenes vurdering og læring (Loughran \& Berry, 2005, s. 199). I forskningslitteraturen understrekes det at modelleringer må kunne adapteres eller transformeres til ulike kontekster, elevgrupper, studenter eller lærerroller. Loughran og Berry forklarer dette som spenninger mellom intension og handling og mellom "telling and growth" og sier at det i dette spenningfeltet ligger muligheter til å språkliggiøre slike spenninger for studentene:

The tension between telling and growth which may be experienced by teacher educators in two ways: between informing and creating opportunities to reflect and self-direct; and, between acknowledging student teachers' needs and concerns and challenging them to grow beyond their immediate pre-occupations (Loughran \& Berry, 2005, s. 199). 


\section{Fride Lindstøl}

Et slikt perspektiv har betydning for lærerutdannerens innramming av modelleringene, som må være åpne nok til å romme studenter med ulike praksiserfaringer og forforståelse, og samtidig sikre at alternative løsninger og fremgangsmåter er tydeliggjort.

Samlet sett viser mitt utvalg av forskningslitteratur tre former for eksplisitte modelleringer. Den første kategorien handler om å modellere praktiske ferdigheter og metoder. I den andre kategorien modellerer lærerutdanneren måter å teoretisere over praktisk lærerarbeid. I den tredje kategorien metareflekterer lærerutdanneren høyt over egen undervisning, for å modellere hvordan egne praktiske og høgskoledidaktiske valg henger sammen med fagstoffet og teorien det undervises i. Selv om det fortsatt finnes få empiriske studier som eksemplifiserer hvordan eksplisitte modelleringsformer virker i en lærutdanningskontekst, antyder forskningslitteraturen at de tre kategoriene kan virke sammen for å skape sammenheng mellom teori og praksis i lærerutdannerens undervisning (Hogg \&Yates, 2013; Ulvik \& Smith, 2016). Studien som rapporteres i denne artikkelen, kan være et slikt bidrag. I neste avsnitt presenteres metoden for prosjektet.

\section{Utvalg og metode}

Denne studien inngår i prosjektet «Tenk hvis - Profesjonsverkstedet i GLU» (Lindstøl et al., 2015). Prosjektet er godkjent av NSD og startet våren 2013. Studien har en kvalitativ tilnærming, med data samlet inn fra tre kilder: Øktagendaer, feltnotater og intervjuer. Innsamling av data fra 100 undervisningstimer ble gjort høsten 2014 og våren 2015. To av lærerutdannerne er norsklærere (NL1 og NL2), og en er matematikklærer (ML3).

\section{Datamaterialet er merket på følgende måter:}

- Feltnotat og øktagenda fra 32 undervisningstimer, norsklærer 1: "FNL1» og «ØNL1»

- Feltnotat og øktagenda fra 32 undervisningstimer, norsklærer 2: «FNL2» og «ØNL1»

- Feltnotat og øktagenda fra 32 undervisningstimer, matematikklærer 3: "FML3» og «ØML3»

- Intervjuer med norsklærer 1, norsklærer 2 og matematikklærer 3: «INL1», «INL2», «IML3》

Planleggingen og gjennomføringen er gjort av lærerteamet og meg selv i rollen som lærerutdanner og forsker. Observasjon, analyse og drøfting er gjort av meg som forsker. Et kriterium for at informantene kunne bli valgt, var at de hadde vært med på å utvikle og undervise i profesjonsverkstedet fra 2013-2015. Lærerutdanningsteamene som deltok i utviklingsarbeidet, hadde en gjensidig avtale om å forske på egen og andres undervisning. Deltakelsen var basert på informert samtykke fra lærere og studenter. Intervjuer med lærerutdannere ble gjort våren 2016 og hadde en varighet på 60 minutter pr. lærerutdanner. Intervjuene tok utgangpunkt i en semistrukturert intervjuguide, som var utviklet ut ifra feltnotater og observasjon av undervisningen. 
Intervjuene ble tatt opp med digital opptaker og deretter transkribert. Både de transkriberte intervjuene i sin helhet og hvordan datamaterialet ble brukt i artikkelen, er godkjent av lærerutdannerne før publisering.

\section{Analyse}

I analysen av datamaterialet ble det viktig å finne en metode som best mulig kunne identifisere både typer, formål og utfordringer med ulike modelleringsformer i datamaterialet. I analysen startet jeg med å gjøre en dramaturgisk analyse av feltnotater og de planlagte øktagendaene til lærerne. Dramaturgi er et fagområde som opprinnelig kommer fra teaterkunsten, og betyr læren om dramaets og scenekunstverkets struktur og funksjoner. Allern beskriver dramaturgi som en måte en fortelling er komponert, presentert og gjennomført på (Allern, 2009, s. 70; Sæbø \& Allern, 2010; Østern, 2014b, s. 10 - 12). Østern er en av dem som har videreutviklet og adaptert kunnskap om dramaturgi i en didaktisk kontekst (Østern, 2005, 2014a, 2014b). I sin forskning forklarer hun dramaturgiske analyser i en undervisningskontekst på denne måten:

Disse analysene kan tilsvare lærerens vurdering av hvilket stoff som kan være underlaget for undervisningens tema, hvordan tema skal transformeres i en spesifikk undervisningsøkt, hva læreren ønsker å legge vekt på, samt elevenes læring, oppfattelse og evaluering av undervisningsøkten (Østern, 2014b, s. 20).

Forskerne og teaterpedagogene Kjølner og Szatkowski (Szatkowski, 1989, s. 122) skriver om perspektiver i den dramaturgiske analysen som rommer transformasjonen fra idé (fagstoff) til giennomført forestilling (undervisning). Østern adapterer perspektivene til en utdanningskontekst, der den dramaturgiske analysen fokuserer på det som skjedde i undervisningens "her og nå», det vil si at feltnotatene språkliggjør det lærerutdannerne og studentene gjør, og det som skjer (Østern, 2014b, s. 20). Den dramaturgiske analysen av undervisning bidro til å identifisere eksplisitte modelleringsformer (episoder) i undervisningsforløpet. Den dramaturgiske analysen identifiserte to former for eksplisitt modellering:

\section{Adapsjon til klasserommet}

2. Modellering av teoretisk metarefleksjon

Den dramaturgiske analysen bidro også til at jeg fikk en oversikt over hvordan de ulike modelleringsformene ble satt sammen (komposisjon), og virket sammen i undervisningsforløpets dramaturgi, et perspektiv som er sentralt for å forstå hvordan ulike modelleringsformer virker sammen. I neste fase gjorde jeg en konvensjonell innholdsanalyse av intervjudata for å identifisere hvordan lærerne selv fortalte om, og begrunnet eksplisitte modelleringsformer i egen undervisningspraksis (Fauskanger \& Mosvold, 2014, s. 135; Hsieh \& Shannon, 2005). Intervjudataene bidro til å få flere stemmer inn $\mathrm{i}$ analysen og ble sammenlignet med den dramaturgiske analysen av 


\section{Fride Lindstøl}

observasjonsdata og øktagendaer fra undervisningsforløpene. Feltnotater og intervjudata har derfor ulik epistemologisk status i studien, noe som blir synlig i analysen som viser at det lærerutdannerne gjør, virker sammen med det de sier at de gjør (Atkinson \& Coffey, 2003, s. 117).

\section{Studiens begrensninger}

Min posisjon i denne studien kan sies å være en «insider», det vil si en person som Kvernbekk (2005) forklarer som «en som på grunn av sin spesielle og privilegerte posisjon innehar - eller antas å inneha - en kunnskap som andre ikke har» (Kvernbekk, 2005, s. 18). Fordi jeg selv er en del av lærerteamet som utvikler profesjonsverkstedet, kan man si at forskerrollen har en privilegert tilgang til egne «intensjoner, persepsjoner, vurderinger, aktiviteter» (Kvernbekk, 2005, s. 31). En slik posisjon kan kritiseres for å skape manglende distanse og avstand til datamaterialet. En insider-posisjon har epistemologiske implikasjoner som stiller store krav til systematisk analyse og datatransparens. I denne casen blir outsider-perspektivet representert ved å fokusere på lærerutdannernes undervisning og individuelle refleksjoner i etterkant, og ved å legge frem analysen til kritisk vurdering for eksterne fagpersoner. Jeg har også vektlagt både en dramaturgisk og en konvensjonell innholdsanalyse, noe som kan bidra til at lærerutdannernes undervisning og refleksjon kommer i forgrunnen $\mathrm{i}$ analysen. For å sikre transparens har utdrag fra de transkriberte intervjuene og feltnotater fått stor plass i presentasjonen av resultaterene fra analysen, som presenteres i neste avsnitt.

\section{Resultater}

I forskningslitteraturen har jeg presentert tre modelleringsformer: Å modellere praktiske ferdigheter og metoder, å teoretisere over praktisk lærerarbeid og å metareflektere og «tenke høyt» over egen undervisning. I mitt materiale har jeg identifisert de to første. Analyse av modellerinsform 1 er presentert i kategori 1, som jeg har kalt «adapsjon til klasserommet». Analyse av modelleringsform 2 er analysert i kategori 2 under overskriften «modellering av teoretisk metarefleksjon». Siden den tredje modelleringsformen ikke er identifisert i mitt materiale, bidrar dette til diskusjonen i den siste delen av artikkelen.

\section{Kategori 1: Adapsjon til klasserommet}

I denne kategorien demonstrerer og eksemplifiserer lærerutdannerne hvordan fagstoffet og temaene de underviser i, kan adapteres til ulike klassetrinn. En situasjon eller en del av et undervisningsforløp gjøres som om det ville vært i klasserommet (Lindstøl, 2016; Lindstøl et al., 2015). Både lærer 1, 2 og 3 simulerte oppstart og avslutning av en time og demonstrerte spesifikke arbeidsformer, metoder og aktiviteter tilpasset ulike trinn og kontekster. Lærer 2 forklarer didaktisk adapsjon på denne måten: 
Jeg forsøker å legge opp undervisningen med elementer som om det skulle vært undervisning i real life. Det er for eksempel en oppstart som jeg forsøker å gjøre reell, eller at jeg bryter en forelesning med øvelser og simuleringer underveis. Jeg sier at nå tenker vi oss at dette stoffet er for 7. trinn og så tar vi 10 minutter. (...) Så viser jeg et eksempel, og studentene må selv adaptere det til et annet trinn (INL2).

Eksempelet viser en veksling mellom at lærere formidler et fagstoff, og at de eksplisitt modellerer adapsjoner av det samme fagstoffet til klasserommet. Som en annen variant av didaktisk adapsion simulerte lærerutdannerne profesjonsspesifikke situasjoner, for eksempel samtaler med foreldre eller utviklingssamtaler med enkeltelever (Lindstøl, 2016). Simuleringene ble modellert sammen med en annen lærerutdanner (L1) og en frivillig student (L3):

Lærer og student sitter midt i rommet med resten av klassen som observatører. Observatørene har fått utdelt begreper som de skal bruke for å observere situasjonen: situasjonsbestemt og strategisk klasseledelse, åpne og lukkede spørsmål, fagspråk og hverdagsspråk, frem- og tilbakemeldinger. Lærer og student samtaler om studentrollen, klassemiljø, faglig progresjon, matematikkfaglige strategier og vekstpunkter, erfaring fra praksis og motivasjon og utfordringer knyttet til det å bli matematikklærer. Lærerutdanneren leder samtalen og bruker språklige strategier (hverdagsspråk og fagspråk, åpne spørsmål, eksempler) for å ramme inn samtalen og sikre at faglige perspektiver (begreper som er delt ut til studenter) blir inkludert (FML3).

Modelleringen fungerte både som et kollektivt eksempel på forventninger, formål, strategier og hindringer knyttet til det å utvikle en lærerrolle, og som en måte å konkretisere og trene på å bruke et fagspråk. I avslutningen av undervisningen ble modelleringen brukt som referanse og erfaring når lærerutdanneren foreleste om transformasjon fra elevrolle til lærerrolle, fra hverdagsspråk til fagspråk og fra en privat til profesjonell læreridentitet.

De tre lærerne fremhever betydningen av å modellere flere alternative løsninger til den samme situasjonen. Lærer 2 forklarer remediering slik: «En måte å modellere på er når jeg er opptatt av delkomponenter og forstørrer enkeltdeler (...) jeg blåser opp små episoder og trener og remedierer dem (ILN2)». Med remediering menes her å modellere flere ulike versjoner av den samme situasjonen, for eksempel ved å bruke ulike medierende redskaper og muntlige uttrykksformer:

Lærerutdanner sier at studentene skal forestille seg at en lærer skal introdusere Peer Gynt for en 8. klasse som ikke har lest Ibsen før. Hun har valgt tre oppstarter med ulike kvaliteter. Alle tar utgangspunkt i Peer Gynts ulike roller og identitet: som forfører, profet, forteller, skrytepave. Hun ber studentene legge merke til hvilke redskaper og kommunikasjonsformer som settes i spill, og hvilke kunnskaper og ferdigheter det kreves av læreren. Hun modellerer tre oppstarter; en muntlig fortelling om Peers entré i bryllupet, en klassesamtale om løken som metafor for identitet, og en aktivitet som kalles kroppen tar stilling som går ut på at ulike forberedte påstander om teksten og tema leses opp og studentene skal reise seg hvis de er enige og bli sittende hvis de er uenige (Lindstøl \& Bakke, 2016, s. 138-139) (FNL1). 


\section{Fride Lindstøl}

Remedieringene gir studentene ulike valg og muligheter og forklares som et konkret og flerstemmig utgangspunkt for at studentene egen utforming og praksis (Lindstøl, 2016). Lærerne påpeker også at modelleringene bidrar til sammenheng mellom faglig innhold i lærerutdanning til praktisk lærerarbeid i klasserommet:

Når jeg adapterer tema til ulike klasserom, tror jeg det er veldig meningsfullt for studentene, det er veldig brukelig for dem. For det første vet jeg jo at når de skal ut å undervise, skal de per dag ha mange former for anslag (...) Det ville vært til stor hjelp hvis man lærte ulike verktøy som typer remedier, artefakter og rekvisitter som finne og brukes der ute (INL2).

Alle lærerne både viser og sier at undervisningsforløpet struktureres slik at modelleringene etterfølges av at studentene selv skal øve seg. Didaktiske adapsjoner prøves ut og adapteres til andre tema og fagstoff, slik at studentene ikke bare kopierer lærerutdannerens forslag:

Hvis jeg viser en modellering, så må de gjøre en annen oppgave etterpå hvor de bruker det inn i noe nytt. Du kan ikke få alt du skal gjøre av andre, du må omsette det til nye situasjoner, du står aleine. Men det å ha gjort aktiviteter hvor de har fått formen på det, for så at de prøver og øver seg er viktig (IML3).

Rammene for modelleringene åpnes gradvis opp ved at lærerutdannerne og studentene remedierer og tranformerer det til nytt innhold og kontekster. Innrammingen forklares av lærer 1 som en premiss for studentenes øvinger og kreativitet:

Jeg tror veldig mye av det sikkerhetsnettet ligger i at vi modellerer først og deretter strammer inn aktiviteten. Vi gir dem rammene som modellerte eksempler, så dytter vi dem. (...) Min erfaring er at det kommer mer ut av stramme rammer og konkrete eksempler enn hvis du slipper det veldig løs. Det kan bli instrumentelt, i verste fall. Men det kan være et trygt sted å starte. Det er mye som tyder på at den kreativiteten ikke blomstrer når man sier "gjør hva du vil». Kreativiteten har mye bedre vilkår når du gir en tydelig oppgave(...) Det er jo den stillastankegangen. Du kan jo ta av det stillaset etter hvert, når studentene har skjønt poenget. Målet er jo at lærerstudentene lager egne oppgaver og didaktiske ressurser (...) Når de har skjønt hvilke muligheter som finnes (INL1).

Oppsummert kan det se ut som det å adaptere lærestoff til klasserommet handler om å simulere deler av undervisningsforløp som for eksempel oppstart av en time. Lærerne legger vekt på å modellere flere løsninger på den samme situasjonen, noe de kaller å remediere. Remedierte modelleringer blir videre brukt som utgangspunkt for studentenes utprøving og trening (Lindstøl, 2016, 2017a). Modelleringer, remediering og utprøvinger settes sammen til ulike deler i undervisningsforløpets dramaturgi. Erfaringene blir videre brukt som referanser og utgangspunkt for å eksemplifisere og utvikle teoretiske begreper og fagpråk. På hvilke måter dette skjer, er utgangpunktet for kategori 2. Kategorien rommer eksplisitte modelleringer av profesjonsspråk og det at lærerutdanneren eksplisitt «tenker høyt» om egen undervisning (modelleringsform $2 \mathrm{og} 3$ som er identifisert i forskningslitteraturen). 


\section{Kategori 2: Modellering av teoretisk metarefleksjon}

Som en del av undervisningsforløpets dramaturgi sier lærerutdannerne at de bygger bro mellom teori og praksis ved å zoome inn på spesifikke didaktiske episoder (kategori 1), for så å reflektere gjennom begreper og overordnet teori. Eksempler fra feltnotater viser hvordan lærerne deler ut spesifikke begreper eller lytteposisjoner som studentene bruker for å observere og analysere en didaktisk modellering (Bakke \& Kverndokken, 2014, s. 56; Børresen, 2016). Det tidligere presenterte eksempelet om oppstart av time (Peer Gynt) blir observert gjennom følgende begreper: situasjonsbestemt og strategisk klasseledelse, redskaper, mediering, muntlig formidling. Begrepene ble brukt som utgangspunkt for kollektive analyser av den modellerte situasionen. Viktigheten av å ha en konkret erfaring som utgangspunkt for analyse fremheves av alle tre lærerne:

Jeg zoomer inn på et lite eksempel, men det sier veldig mye om et stort tema som for eksempel er klasseledelse. Jeg har veldig tro på å jobbe sånn (...) sette mikroskopet på noe fordi det belyser noe mye større (...) Det kan ikke bare være en giøring, jeg må hele tiden trekke det tilbake til den teorien vi tok utgangspunkt i. Det øyeblikket du bare jager fra aktivitet til aktivitet så rakner det. Vi må synliggjøre hva gjorde vi nå, hva har det med teoriene å gjøre. Det er viktig med de mellomrommene mellom aktivitetene. Det er lettere å få dem til å reflektere når de har gjort noe og har kjent det på kroppen (...) målet er jo hele tiden å bygge bro mellom aktivitetene (...) Faren med å modellere ulike eksempler uten å koble til teori er at det blir masse gjøringer og tivoli og moro uten at noen har lært noe (INL1).

I eksempelet ovenfor tematiseres forholdet mellom erfaring og analyse og at studentene må øve seg på å bruke teori til å begrunne og samtale om praktisk lærerarbeid. Slike analyser modelleres eksplisitt giennom at lærerutdanneren selv bruker overordnede begreper for å ha et metaperspektiv og et profesjons- eller fagspråk på noe som er gjenkjennbart:

Alle trenger å kunne ha et metaperspektiv på det hverdagslige de gjør, heve blikket og prøve å sette ord på det som blir enn hverdagsprat, med fagspråk. Jeg tror det har noe med profesjonalisering å gjøre. Det at man har felles begreper for det man driver med tror jeg er enormt viktig. Jeg opplever at noe av begrepene fra pedagogikken er anvendelige men at de ikke blir omsatt til en hverdagsvirkelighet som studentene trenger dem i. Det blir litt livsfjernt. Jeg har jo veldig tro på teoretiske begrep og kategorier å tenke i, men det må og materialisere seg i noe som er gjenkjennbart. Og det er det vi har fått gjort når vi modellerer didaktiske situasjoner. Vi undersøker for eksempel hva betyr å være i et sosiokulturelt skole-hverdagsliv, hva er å differensiere (INL2)?

Lærer 1 forklarer sammenhengen mellom didaktiske adapsjoner (kategori 1) og metarefleksjon (kategori 2) som å bygge bro mellom norskfaglig tema, praktisk lærerarbeid og pedagogikk:

Lærerne modellerte åtte forskjellige oppgaver og redskaper som kunne brukes for å bygge bro mellom tema sosiolingvistikk, undervisningstema i praksis (skrive filmmanus, tegneserie, skriftlig og muntlig argumentasjon) og et utvalg pedagogisk 
teori. En oppgave tok utgangpunkt i mikrofigurer i plast og plastelina for at studentene skulle skrive replikker for å eksperimentere med dialekter, sosiolekter, ordvalg og talehandlinger. En annen oppgave handlet om at studentene skulle kategorisere språklige ytringer og sosiolingvistiske begreper og forklare disse til ulike fiktive målgrupper som for eksempel barn, eksperter, ungdom. Oppgavene ble analysert av studenter og faglærere. Fokus for analysen var på hvilken måte oppgavene (utforming, redskaper, språk) satte i spill elevenes erfaringer og kunnskaper fra arenaer utenfor skolen som for eksempel fritid, populærkultur, familieliv og hverdagsspråk (FNL2).

I dette undervisningsforløpet hadde oppgavene en tredobbel funksjon: For det første å modellere didaktiske strategier som kunne brukes i klasserommet, for det andre å bidra til at studentene språkliggjorde kunnskaper om sosiolingvistikk og praktisk lærerarbeid. For det tredje ble oppgavene konkrete og flerstemmige erfaringer som kunne brukes som utgangpunkt for kollektive analyser gjennom sosiokulturell læringsteori. Lærer 1 forklarer trianguleringen på denne måten:

\begin{abstract}
Det var jo kombinasjonen av sosiolingvistikk fra høgskolens side, bygge bro mellom hverdagskunnskap og skolsk kunnskap som overordnet idé. Praksislærerne hadde bestilt inn temaer som dialoger, tegneserier og argumentasjon. Sammen oppdaget vi at det var flere muligheter med å jobbe med sosiolingvistikk enn man hadde tenkt seg fra før. Hvor de språklige og norskfaglige perspektivene ble veldig tydelig. Det krevde også at alle deltagerne koblet seg på og forsøkte å konkretisere de overordnede perspektivene som i dette tilfellet handler om brobygging mellom elevenes livsverden og det skolske innholdet, mellom ulike kunnskapspraksiser (INL1).
\end{abstract}

Metaforen å bygge bro blir i dette eksempelet brukt for å forklare hvordan temaet sosiolingvistikk adapteres og modelleres til didaktiske strategier, som videre analyseres gjennom et utvalg pedagogiske perspektiver. Analysearbeidet formgis av studentene selv. Et eksempel er når en student påpeker at hun egentlig ikke skjønner helt hva det å bygge bro mellom ulike kunnskapspraksiser betyr, eller hva en kunnskapspraksis er. Læreren svarer at det kan være mye forskjellig, det er avhengig av hvilket kunnskapssyn man har. Hun sier videre at studentene kan snakke sammen to og to om hvordan de forstår ordet «kunnskapspraksis» (FNL1). Analysen antyder at det er en kontrast mellom det lærerutdannerne gjør, og det de sier: De sier at det å modellere hvordan studentene bruker et fagspråk, er like viktig som å modellere didaktiske ferdigheter. Likevel viser verken øktagendaer eller feltnotater mange eksempler på eksplisitte modelleringer av hvordan teori og fagspråk kan gi form til analyse av praktisk lærerarbeid.

I selve undervisningssituasjonen bruker lærerutdannerne erfaringer fra didaktiske adapsjoner til å kommentere egen undervisning, og til å gi tilbakemelding på studentenes styrker og vekstpunkter. I disse kommentarene ble det lagt vekt på å bruke fagspråk, som for eksempel «matematisk argumentasjon» og «rike oppgaver». Eksempelet nedenfor viser hvordan lærerudanneren reflekterer over egen undervisning:

Lærer 3 starter med å modellere aktiviteten «odd one out», som går ut på at fem ulike brøker og desimaltall skrives opp på tavla. Studentene blir bedt om å 
argumentere matematisk for hvilken verdi som ikke passer inn i mengden. Studentene foreslår ulike svar, flere strever med å argumentere. Lærer 3 påpeker dette og sier at en forutsetning for å kunne gjennomføre matematiske samtaler i klasserommet er at studentene har god kjennskap til fagstoff, øver på å stille presise spørsmål og selv kan argumentere matematisk. Hun sier: Ut ifra erfaring med aktiviteten "odd one out» kan jeg se at noen av dere trenger å trene på matematisk argumentasjon i arbeid med brøk. Derfor vil jeg nå prøve ut en rikere oppgave, det vil si en oppgave som rommer flere løsninger med ulik vanskelighetsgrad(FML3).

Eksempelet viser hvordan lærerutdanneren justerer og begrunner didaktiske valg i møte med studentene. Gjennom å språkliggjøre erfaringer fra didaktisk aktivitet modellerer lærerutdanneren hvordan formativ vurdering kan skje i et undervisningsforløp. Jeg har derfor kategorisert denne interaksjonen som modelleringsform 2, selv om den har noen kjennetegn fra modelleringsform 3. Det er fordi lærerutdanneren til en viss grad «tenker høyt» og responderer på studentenes respons på oppgaven. Modelleringen kan karakteriseres som delvis eksplisitt fordi didaktiske valg begrunnes ut ifra erfaringen fra aktiviteten. Likevel vet man ikke om sammenhengen mellom valg av aktivitet, erfaring og formativ vurdering er eksplisitt nok til at studentene klarer å overføre erfaringen til de selv skal lede matematiske samtaler.

Oppsummert kan analysen av kategori 2 plasseres i grensen mellom implisitt og eksplisitt modellering. Øktagendaene viste ikke spor av planlagte eksplisitte modelleringer av teoretiske analyser eller profesjonsspråk. I feltnotatene observerte jeg at lærerutdannerne uttrykte hvor viktig det var at studentene lærte å reflektere gjennom et profesjonelt språk, og at dette var noe som måtte øves på. Det ble også lagt til rette for øvinger og kollektive analyser av praktiske eksempler, hvor lærerutdannerne bidro med spørsmål og innspill. Likevel observerte jeg ikke eksplisitte modelleringer av hvordan teorier og begreper kunne gi form til analysen. Analysen av feltnotater viser ingen gode eksempler på den tredje modelleringsformen hvor lærerutdanneren «tenker høyt» om egen undervisning og justerer planen og kursen ut ifra studentenes handlinger og språk. Oppsummert viser analysen at eksplisitt modellering av metarefleksjon og et profesjonsspråk kan være et potensielt vekstpunkt i lærerutdannernes undervisning.

Resultater fra analysen av kategori 1 og 2 kan visualiseres i en modell som viser en trinnvis utvikling fra implisitt til eksplisitt modellering - en modelleringsstige. Modellen er ikke knyttet til undervisningskvalitet (dårlig - bra), men kan bidra til at lærerutdanneren kjenner til og tar begrunnede valg når eksplisitte modelleringsformer skal implementeres i undervisningen. Det første trinnet viser implisitt modellering som tidligere har blitt forklart som å undervise eksemplarisk, uten å forberede eller markere at "dette er en modellering». Trinn to viualiserer en enkel didaktisk adapsjon som medieres gjennom en modalitet, for eksempel tekst, bilde, fortelling. Trinn tre viser en remediering, det vil si at den didaktiske situasjonen adapteres og medieres på minst to ulike måter. Remedieringen etterfølges i trinn fire av øvinger, der studenten selv kan velge mellom ulike versjoner av den didaktiske adapsjonen. I trinn fem brukes det profesjonsspråk og teori for å refelektere over de didaktiske adapsjonene. I det siste og sjette trinnet modellerer lærerutdanneren en eller flere 


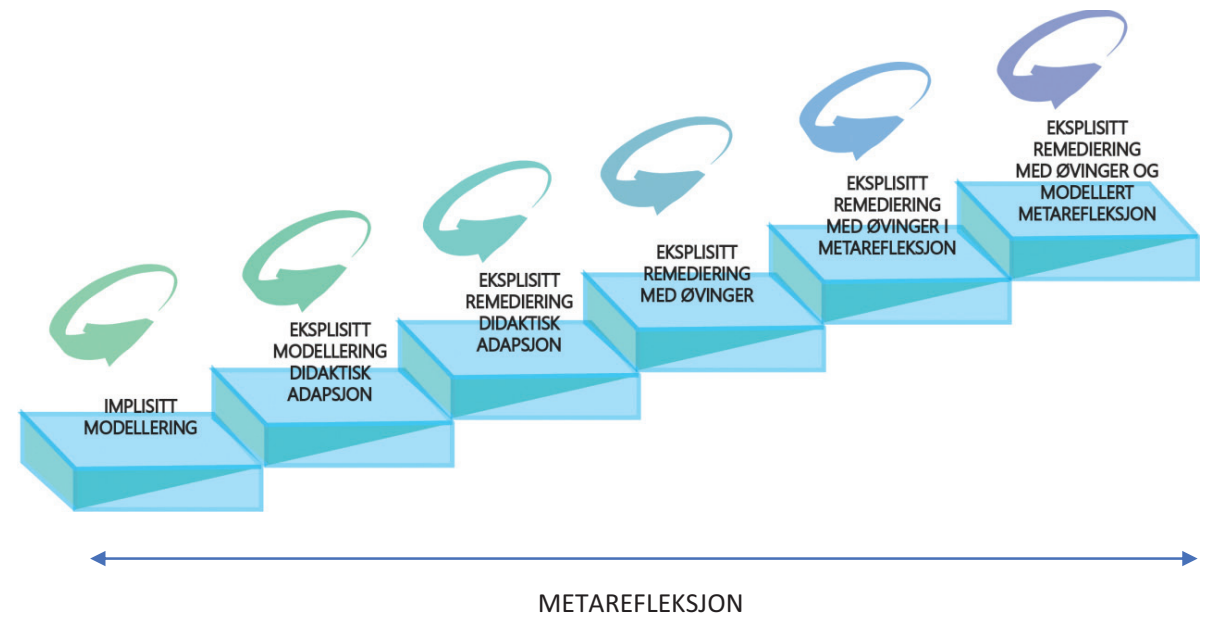

Modell 1. Modelleringsstigen viser en trinnvis utvikling fra implisitt til eksplisitt modellering. Hvert trinn kan utformes som en egen struktur eller dramaturgi eller kobles til de andre trinnene i stigen.

analyser som viser hvordan begreper og teori virker som analytiske briller. Hvert trinn tilbyr en egen dramaturgi som kan brukes som en enkelt del/episode i undervisningforløpets dramaturgi. Stigen kan også brukes som modell for å planlegge hele undervisningsforløp og som et utgangpunkt for metarefleksjon og «thinking aloud» om egen undervsining (Loughran \& Berry, 2005, s. 590).

Trinnene i stigen gir en oversikt over hvordan modellering av didaktiske adapsjoner og teoretisk metarefleksjon kan (hvis det er brukelig og ønskelig) bli mer og mer eksplisitte. Modellen vil utdypes i neste del og brukes som utgangspunkt for å drøfte resultatene i forhold til tidligere presentert forskning og teori.

\section{"Vi gir dem rammene som modellerte eksempler, så dytter vi dem» - avsluttende drøfting}

Artikkelen ble innledet med å identifisere det som Loughran og Berry kaller spenningen mellom "telling and growth» (Loughran \& Berry, 2005, s. 199), et perspektiv som også blir kommentert av en av lærerutdannerne i prosjektet: «Du kan jo ta av det stillaset etter hvert, når studentene har skjønt poenget» (INL2). På den ene siden handler spenningen om å sikre grunnleggende undervisningsferdigheter, et didaktisk repertoar og en grunnleggende teoretisk forståelse, og på den andre siden åpne opp for variasjon, utvikling og nytenkning. En fare er at eksplisitte modelleringer virker som en altfor trang mal eller oppskrift, som verken åpner opp for studentens eller profesjonens utprøving eller lar seg kritisere av deltagerne i læringsfelleskapet. Modelleringsstigen, som forstås som en visualisering og sammenkobling av tre lærerutdanneres undervisningspraksis, kan bidra til å balansere forholdet mellom «telling and growth", noe som er utgangpunkt for å drøfte resultatene av analysen i forhold til tidligere presentert forskning på eksplisitte modelleringsformer. 
Resultatene av analysen i forrige del viser eksempler på hvordan lærerutdannerne setter sammen ulike modelleringsformer til undervisningen. Analysen av datamaterialet viser flere måter å åpne opp eksplisitte modelleringer på. En viktig strategi er at en didaktisk adapsjon remedieres gjennom å bruke ulike redskaper og uttrykksformer. Remedieringen ser ut til å åpne opp for flere alternative løsninger, noe som kan virke som et mer flerstemmig utgangspunkt for studentenes adapsjon til egen lærerrolle og forforståelse. En annen viktig strategi er at remedieringer etterfølges av at studentene selv øver og adapterer modelleringen til egen praksis ved å dele, vise og reflektere over hverandres forslag og løsninger i læringsfellesskapet. En tredje strategi er at modellerte didaktiske situasjoner og studentenes øvinger analyseres og dekonstrueres gjennom teori og fagspråk. Først skjer dette gjennom lærerens eksempler, deretter prøver studentene ut analyser gjennom å selvstendig utforske lytteposisjoner og roller (Bakke \& Kverndokken, 2014, s. 56; Lindstøl, 2016).

Som tidligere nevnt, kan dramaturgiske analyser brukes til å synliggiøre hvordan et fagstoff transformeres til undervisning, og hva som skjer i undervisningens «her og nå»-perspektiv. Dramaturgiske analyser kan også bidra til å identifisere episoder (deler) i forløpet, for så å undersøke hvordan episodene settes i spill og konsentrerer ulike kunnskapsformer og betydningslag i fagstoffet (Østern, 2014b, s. 20). I denne sammenhengen visualiserer modelleringsstigen noen dramaturgiske muligheter, fra å observere til å giøre, fra å kopiere til å videreutvikle og fra å erfare til å reflektere gjennom teori og profesjonsspråk. Hvert trinn på stigen viser en form for struktur og progresjon som benytter seg av ulike dramaturgier. Et eksempel er når lærerutdannerne modellerer en didaktisk situasjon gjennom å bruke ulike redskaper. Remedieringen kan forstås som en form for sirkulær dramaturgi, hvor innholdet gjentas gjennom å ta $\mathrm{i}$ bruk ny form og nye redskaper som medierer innholdet på ulikt vis (Lindstøl, 2014). En sirkulær dramaturgi kan også brukes for å forstå hvordan ulike teoretiske begreper og fagspråk fokuserer tolkningen og studentenes metarefleksjon på ulikt vis. Det betyr at modelleringsstigen ikke må ses på som en sekvensiell modell, der for eksempel trinn to bygger på trinn en, men at hvert trinn tilbyr sirkulære prosesser, som kan kombineres og settes sammen til hele undervisningsforløp.

Selv om analysen viser empiri fra flere ulike undervisningsforløp, vil jeg også foreslå at modelleringsstigen som helhet kan brukes til å planlegge ett undervisningsforløp, hvor lærerutdanneren velger flere trinn i en dramaturgisk komposision (Lindstøl, 2016, 2017a). Enkelte trinn kan settes sammen og tilpasses studenter med ulike erfaringer og ulik teoretisk forforståelse. Studenter som skal innvies i et tema og i en praksis, kan ha bruk for både eksplisitte modellerte didaktiske adapsjoner og eksplisitt modellerte metarefleksjoner. Studenter og lærere som har mer erfaring, kan i større grad utforme og velge remedieringer og analytiske begreper selv for så å teste ulike løsninger i læringsfelleskapet. Mellom implisitt og eksplisitt modellering får lærerutdannerne mulighet til å utnytte spenningen som er i undervisningsøyeblikket, samtidig som basisferdigheter og begreper sikres. En slik måte å komponere et undervisningsforløp på, ser ut til gradvis å frigjøre studentene fra stillaset som modelleringen tilbyr. På en måte kan dette representere et paradoks: jo mer eksplisitt lærerutdanneren planlegger sin undervis- 


\section{Fride Lindstøl}

ning, desto mer ser det ut til å åpne opp for flerstemmige praktiske løsninger og profesjonsspråk for uerfarne studenter (Østrem, 2009).

I analysen av datamaterialet ser det ut til at lærerutdannerne sjelden eksplisitt modellerer hvordan teoretiske analyser kan utformes og best mulig gjøres. Dette overlates i stor grad til studentene selv. Dette trinnet (som visualiseres i modelleringsstigens øverste trinn) kan derfor karakteriseres som et vekstpunkt i lærerutdannernes undervisning og undervisningsforløpets dramaturgi, et perspektiv som utdypes i neste del.

\section{«Alle trenger å kunne ha et metaperspektiv på det hverdagslige de gjør»- bro mellom praksis og teori.}

Forskning viser som nevnt at det å eksplisitt vise arbeidsformer og metoder ikke er nok, studentene må også bli oppmuntret til å reflektere over meningen med modelleringen (Loughran \& Berry, 2005, s. 193, 200; Ruys et al., 2013). En måte å koble teori og praksis på er å forklare underliggende pedagogiske valg og knytte disse til teori ved å tilføre metakommentarer (Ruys et al., 2013; Ulvik \& Smith, 2016, s. 63). I denne studien viser analysen hvordan remediering av didaktiske adapsjoner skaper kollektive erfaringer, som studentene reflekterer over gjennom spesifikke begreper og pedagogisk teori. Empirien viser eksempler på hvordan lærerutdanneren modellerer praktisk lærerarbeid som tar utgangspunkt i, og setter i spill, temaet sosiolingvistikk på ulike vis (s.11). Oppgavene brukes som utgangspunkt for at studentene kan erfare, øve seg og samarbeide om å bruke fagbegreper og et profesjonsspråk.

I analysen er strategier for hvordan lærerutdanneren kan modellere teoretiske analyser fortsatt litt uforløst. En mulig begrunnelse kan være at metoder og strategier for å utvikle muntlige ferdigheter knyttet til teoretiske analyser ikke har vært særlig utviklet i lærerutdanningen (Angelo, 2016; Østrem, 2009, s. 372). En annen begrunnelse kan være at det å eksplisitt modellere slike analyser krever mye forberedelses- og samarbeidstid. Hvilke perpektiver og teorier som skal prioriteres, og hva som karakteriseres som relevante modelleringer, utfordrer lærerutdannernes kompetanse og kjennskap til profesjonen (Ulvik \& Smith, 2016). Fallhøyden knyttet til å eksplisitt modellere teoretiske analyser er stor, og kan resultere i at gode eksempler på praktisk lærerarbeid sløres til eller drukner i komplekse teoretiske begreper, eller i motsatt fall at teori ikles en praktisk tvangstrøye, hvor alt må konkretiseres og kobles til praktisk lærerarbeid for å ha relevans for studentene og utdanningen. I denne sammenhengen viser modelleringsstigen hvordan teoretiske perpektiver og fagspråk fra flere fag kan virke sammen og tilby ulike tolkninger av praktiske situasjoner (Lindstøl, 2017a). Lærerutdannerne må ikke være enige om et begrep eller perpektiv. Stigen rommer flere muligheter og forslag fra ulike fagtradisjoner og paradigmer. På den måten kan motsetninger og flerstemmighet bli en drivkraft, som åpner opp og skaper spenning i undervisningen (Ulvik \& Smith, 2016, s. 63). I lærerfelleskapet kan samtaler som tematiserer hvordan teoretiske perspektiver kan brukes til å analysere praktisk lærerarbeid, bli en måte å utvikle lærerutdannerens kompetanse og profesjonalitet. 
En tredje modelleringsform som forskningslitteraturen peker på, er muligheter som ligger i å kunne teoretisere og "think aloud» over egen undervisning (Loughran \& Berry, 2005, s. 590). Analysen av feltnotater viser få eksempler på hvordan lærerutdannerens modelleringer gir mulighet til å gi spontane, muntlige og formative fremovermeldinger til studenter. Dette kan også ha sammenheng med at det å utsette seg for åpen vurdering og kritikk oppleves som risikofylt, noe som tematiseres i neste avsnitt (Berry, 2007; Loughran \& Berry, 2005, s. 199).

\section{«Kanskje vi må tåle å ikke kunne alt» - lærerutdanneren mellom risiko og kontroll}

Analysen viser eksempler fra tre lærerutdannere som utfordrer egen praksis og utsetter seg for risiko gjennom å modellere og remediere didaktiske eksempler. Både det å iscenesette seg selv som rollemodell og det å åpent reflektere over egen undervisning sammen med studentene kan innebære risiko (Biesta, 2014; Loughran \& Berry, 2005). En risikofaktor er at pedagogisk teori og fagstoff som tidligere er undervist $i$, viser seg å være ukjent for studentene, noe som kan føre til overfladiske analyser og overfladisk forståelse av modelleringene. En annen risiko er hvis modelleringer av didaktiske adapsjoner ikke blir vellykket. Da hviler undervisningsforløpet på ustø grunn når studentene selv skal prøve ut og dele egne forslag i læringsfelleskapet. Som en kontrast til risikoperspektivet viser analysen at eksplisitte modelleringer også kan bidra til en form for kontroll. Et eksempel er når faglærer 2 har forberedt ulike redskaper og formidlingsformer for å starte opp en time (jamfør eksemplet om Peer Gynt s. 9). Et annet eksempel er når faglærer 3 har valgt ut teoretiske begreper som studentene skal trene på å bruke for å analysere en simulert utviklingssamtale (s. 8). Det at lærerutdannerne bestemmer hva som skal settes i spill, gir en mulighet til å få oversikt over studentenes forforståelse og gi direkte tilbakemelding på studentenes vekstpunkter og styrker, ut ifra "her og nå»-erfaringer i undervisningen. I tillegg vil det å forberede, utforme og modellere analyser og didaktiske adapsjoner ramme inn læringsarbeidet og delvis kunne kontrollere hvilke kunnskapsformer og teoretiske perspektiver som settes i spill i undervisningen. Denne formen for kontroll kan virke inn på forventninger som praksislærere og lærerutdannere har til studentens didaktiske repertoar. Et annet eksempel er hvordan studentene artikulerer sammenhenger mellom praktisk lærerarbeid, profesjonsspråk og teori.

Modelleringsstigen kan i denne sammenhengen fungere som et redskap til å planlegge, giennomføre og analysere undervisning. Ut ifra modelleringsstigen kan lærerutdanneren bestemme hvilke trinn i stigen som er mest hensiktsmessige for undervisningen og studentenes nivå og forforståelse. Modelleringsstigen kan også være et utgangspunkt for å samtale om og analysere undervisningens komposisjon og progresjon, og på den måten representere et didaktisk modelleringsrepertoar. Samarbeid om hvilke didaktiske eksempler som er relevante, og hvilke teoretiske begreper som kan kontrastere og åpne opp lærestoffet, kan utfordre og utvikle lærerutdanneren. På den måten kan også lærerutdanneren iscenesette og modellere en rolle som ligner på den studentene selv må utvikle 
i klasserommet, en lærer som daglig eksplisitt modellerer strategiske eksempler og tekster som ikke alltid blir forstått eller mottatt på en god måte av elevene.

Dermed kan lærerutdanningen være en arena hvor studentene møter lærerutdannere som samarbeider om å utvikle autentisk, kreativ og nyskapende praksis, og som tør å utsette seg for risiko på en kontrollert og gjennomtenkt måte.

\section{Biografi}

Fride Lindstøl er førstelektor og stipendiat på programmet «Pedagogiske ressurser og læreprosesser» ved Høgskolen i Sørøst-Norge. Hun har ledet utviklingen av "profesjonsverkstedet», som er en fagovergripende arena for å utvikle og forske på undervisningskvalitet i lærerutdanningen. Arbeid med profesjonsverkstedet fikk den nasjonale utdanningskvalitetsprisen i 2014.

\section{Referanser}

Aleccia, V. (2011). Walking our talk: The imperative of teacher educator modeling. Clearing House: $A$ fournal of Educational Strategies, Issues and Ideas, 84(3), 87-90. doi: 10.1080/00098655.2010.524951

Allern, T. H. (2009). Fagdidaktikk $i$ drama-dramaturgi $i$ undervisning og lering. (B. Kompendium nr. 885.): Dramaseksjonen: Høgskolen i Nesna.

Angelo, E. (2016). Lærerutdannerens profesjonsforståelse: En innfallsvinkel til å profesjonalisere lærerutdannerfeltet. Acta didactica Norge [elektronisk ressurs], 10(2), 108-131.

Atkinson, P. \& Coffey, A. (2003). Revisiting the relationship between participant observation and interviews. I J. F. Gubrium \& J. A. Holstein (red.), Postmodern Interviewing (s. 102-122). London: Sage.

Bakke, J. O. \& Kverndokken, K. (2014). Muntlig bruk av språket. I H. Traavik \& B. Kolberg Jansson (red.), Norskboka 1. Norsk for grunnskolelcererutdanningen 1-7 (s. 53-81). Oslo: Universitetsforlaget.

Berry, A. (2007). Tensions in teaching about teaching: Understanding practice as a teacher educator (B. 5): Springer Netherlands.

Biesta, G. J. J. (2014). Utdanningens vidunderlige risiko. Bergen: Fagbokforlaget.

Fauskanger, J. \& Mosvold, R. (2014). Innholdsanalysens muligheter i utdanningsforskning. Norsk pedagogisk tidsskrift, 98(2), 127-139.

Gallimore, R. \& Tharp, R. (1992). Teaching mind in society: Teaching schooling and literate dicourse. I L. C. Mol (red.), Vygotsky and education: Instructional implications and applications of sociohistorical psychology (s. 175-205). Cambridge: Cambridege university press.

Hogg, L. \& Yates, A. (2013). Walking the talk in initial teacher education: Making teacher educator modeling effective. Studying Teacher Education, 9(3), 311-328. doi: 10.1080/17425964.2013.831757

Hsieh, H.-F. \& Shannon, S. E. (2005). Three approaches to qualitative content analysis. Qualitative Health Research, 15(9), 1277-1288.

Kvernbekk, T. (2005). Pedagogisk teoridannelse: Insidere, teoriformer og praksis. Bergen: Fagbokforlaget.

Lindstøl, F. (2014). Mål tid(en): Dramaturgiske og kunnskapsteoretiske implikasjoner til en pragmatisk estetikk. InFormation - Nordic fournal of Art and Research, 3(2), 110-128. Hentet fra http://www.artandresearch.info/

Lindstøl, F. (2016). Tenk hvis - Om fiksjonserfaringer som utgangspunkt for refleksjon i lærerutdanningen. Acta didactica Norge, 10(3), Art. 14.

Lindstøl, F. (2017a). Fra tekst til episode - en dramaturgisk analyse av lærerens undervisning. I K. Kverndokken, N. Askeland \& H. H. Siljan (red.), Kvalitet og kreativitet $i$ undervisning (s. 145-168). Oslo: Fagbokforlaget

Lindstøl, F. \& Bakke, J. O. (2016). 17 muntlighetsgrep. I K. Kverndokken (red.), 101 måter å fremme muntlige ferdigheter på - om muntlige ferdigheter og muntlighetsdidaktikk (s. 138-147, 164-165, 198-211, 224-229). Oslo: Fagbokforlaget.

Lindstøl, F., Bakke, J. O. \& Moe, M. (2015). As if. Om profesjonsverksted i GLU. I E. K. Høihilder \& O. A. Gulbrandsen (red.), Pedagogikk og elevkunnskap i grunnskolelcererutdanningen: PEL $i$ GLU (s. 305-314). Oslo: Gyldendal akademisk.

Loughran, J. \& Berry, A. (2005). Modelling by teacher educators. Teaching and Teacher education, 21(2), 193-203. 


\section{Mellom risiko og kontroll - en studie av eksplisitte modelleringsformer $i$ norsk}

Lunenberg, M., Korthagen, F. \& Swennen, A. (2007). The teacher educator as a role model. Teaching and Teacher Education, 23(5), 586-601. doi: 10.1016/j.tate.2006.11.001

Ruys, I., Defruyt, S. \& Aelterman, A. (2013). Differentiated instruction in teacher education: A case study of congruent teaching. . Teacher and teaching: Theory and practice. 19(1), 93-107.

Smith, K. (2005). Teacher Educators' professional knowledge - How does it differ from teachers' professional knowledge? Teaching and Teacher Education, 21, 177-192.

Szatkowski, J. (1989). Dramaturgiske modeller - om dramaturgisk tekstanalyse. I E. E. Christoffersen, T. Kjølner \& J. Szatkowski (red.), Dramaturgisk analyse. En antologi (B. 24, s. 9-92). Århus: Universitetet i Århus, Institutt for dramaturgi.

Sæbø, A. B. \& Allern, T. H. (2010). Hva kan drama som læringsform bidra med i undervisnings- og læringsprosessen? Norsk pedagogisk tidsskrift, 94(3), 244-255.

Ulvik, M. \& Smith, K. (2016). Å undervise om å undervise - Lærerutdanneres kompetanse sett fra deres eget og fra lærerstudenters perspektiv. Uniped, 39(1), 61-77.

Østern, A.-L. (2005). Drama, dramaturgi och kulturell läsfärdighet (B. 10). Åbo: Akademien. SMLF årsskrift.

Østern, A.-L. (2014a). Å tenke som en dramaturg i undervisningen. I A.-L. Østern (red.), Dramaturgi i didaktisk kontekst (s. 19-37). Bergen: Fagbokforlaget.

Østern, A.-L. (red.). (2014b). Dramaturgi i didaktisk kontekst. Bergen: Fagbokforlaget.

Østrem, S. (2009). Lærerutdanningens bidrag i læreres kunnskapsutvikling. Nordic Studies in Education, 29(04), 369-383. 